Uşak Üniversitesi Sosyal Bilimler Dergisi

$2015,8 / 1$

\title{
Hollywood Sinemasında Baştan/Yoldan Çıkarıcı Kadın Figürünün Dönüșümü
}

\author{
Burak BAKIR \\ Emrah Suat ONAT ${ }^{* *}$
}

\begin{abstract}
Özet
Klasik Hollywood sinemasında ortaya çıan temel izleklerinden birisi olan baştan çıkarıcı/ölümcül kadın (femme fatale) 1930'larda kentleşme ve tüketim olgusunun ön plana geçmesiyle de belirginleşmeye başlayan ataerkillik krizine bir yanıttır. Klasik filmlerde erkek egemen söyleme ait fantezinin bir ürünü olarak onun erki ve ahlakını onaylar. Özellikle 1980'lerde ortaya çıkmaya başlayan Hollywood filmlerindeki baştan çıkarıcı kadın karakter ise 1940'lardaki temsilinden ayrılır. Onlar erkek fantezisini erkeğe ait bir kategori olmaktan çıartarak bizzat gerçekleştirirler. İkisi arasında böylelikle temel bir yapısal fark vardır; birincisi erkek egemen söylemi tehdit etmek şöyle dursun son kertede onu güvence altına alır, ikincisi ise erkeğin tüm egemenliğine son verir. Bunu yaparken de, kendisini, öncelikle erkeğin karşısına bir nesne olarak koyarak (kendisini metalaştırarak) gerçekleştirir. "Katı olan her şeyin buharlaşttğı" yönündeki sav, meta ilişkileri düzleminden toplumsal hayat ve aileye de sirayet ederek ataerkil olanın gücünü yok ederken, bunun yansıması sinemada kendisini pek çok açıdan göstermektedir ki Hollywood sinemasında baştan çıkarıcı kadın figürünün evrimi de bunu ortaya koymaktadır. Diğer yandan da bu süreç boyunca görsel-işitsel imge üretiminin temsili düzeyden pornografi düzeye geçişinin, gizleyici imgeden şeffaf imgeye, tüm çıplaklığı ile karşımızda duran ve arkasında hiç bir şey barındırmadığı izlenimi veren bir imgeye geçtiğini görmek mümkündür. Son olarak da Klasik Hollywood sineması ile günümüz sineması arasında bakışın (gaze) kurgulanması noktasında söz konusu kadın figürü üzerinden ontolojik bir kaymaya işaret edilebilir. Ne var ki bu ontolojik kaymanın Hollywood sineması için imge üretiminde politik/ideolojik bir kopuşu meydana getirdiğini söylemek pek mümkün görünmemektedir.
\end{abstract}

Anahtar Kelimeler: Hollywood Sineması, Kadın Temsili, Bakış, Görsel Haz.

* Öğr. Gör. Dr., Dokuz Eylül Üniversitesi Güzel Sanatlar Fakültesi

** Arş. Gör. Dr., Dokuz Eylül Üniversitesi Güzel Sanatlar Fakültesi 


\title{
The Transformation of Seductive Woman Figure in Hollywood Cinema
}

\begin{abstract}
Seducing women / deadly women (femme fatale) theme (one of the main features of classical Hollywood cinema) is a response to the crisis of patriarch which becomes clear when the urbanization and consumption came to the forefront in 1930's. It approves, as being the male dominant discourse's phantasy, the power and ethics of this discourse in classical Hollywood movies. However, with the emergence of seducing woman characters in 1980's, this characterization differs from the one in the 1940's. The new woman character not only discards the male phantasy's place as being a category only belong to men, but she realizes it. There is a fundamental difference between the two: First, far from threatening the male dominant discourse, it assures it; second, it puts an end to the male's dominancy. And while doing so, puts itself in front of the male as an object (it commoditizes itself). The idea that "everything solid evaporates" spreads from commodity relations to the social life and family and destroys the patriarch. The reflections of this process show itself in the cinema and the evolution of seductive woman figure in Hollywood cinema confirms this. On the other hand it is possible to see image production evolves from representative phase to pornographic phase, from hidden image to the transparent image, to the image that stands there naked and never hiding anything behind. Finally, the fictionalization of the gaze between classical Hollywood cinema and today's cinema may point to an ontological lapse in regard to women's representations. However it is hard to say for this ontological lapse to cause a political/ideological disengagement on image production in Hollywood cinema.
\end{abstract}

Key Words: Hollywood Cinema, Representation of Women, Gaze, Visual Pleasure.

Hollywood sineması, tüm ulusal anaakım sinemaları gibi -ve hatta onların atası olarak- cinsiyetçi eril bir bakışa sahiptir. Bu bakışı kurar, yönlendirir, vazgeçilemez kılar. Dünyanın en büyük ve en yayılmacı sinema endüstrisi olarak yıllardır izleyicinin gözünü bu eril bakışı yadırgamayacak ve hatta benimseyecek biçimde eğitmiştir. İdeolojik yapısıyla seyircisi arasında ayırım yapmayarak birbirinden farklı olan izleyici kitlesini tek bir birey haline dönüştürür. $\mathrm{Bu}$ nedenle anaakım sinema erkek/kadın, genç/yaşlı, zengin/fakir ya da ten rengi ayrımı yapmaz; bu tek seyirci beyaz, orta sınıf, heteroseksüel erkektir. Bu değerler aynı zamanda Amerikan 
şirketleşmiş kapitalizminin temel direkleridir ve bunları korumayı güvence altına almak adına cinsiyetçi bakışı kullanırken, bu eril bakışı alternatifsizmiş gibi yapılandırır. Bu nedenle, bu bakışın kökenlerini anlamak ve üzerine kurulduğu zemini kavrayarak bugün geldiği konumu çözümleyebilmek için anaakım sinemanın anlayışının kökeni olan Hollywood tarihinde kadının ve kadına yönelen eril bakışın ve yargının ve hükmün tarihini ele almak faydalı olacaktır.

Amerikan sinema tarihinin erken dönemini teşkil eden 15-20 yıllık New York süreci bir yana bırakılacak olursa Hollywood sineması tarihi 1920'lerle başlar. I. Dünya Savaşı'nın ardından yaşanan Viktoryen ahlaktaki gevşemeler ve yine savaşa bağlı olarak ekonomik büyüme ve güçlenme 20'lere damgasını vurur. Amerikan toplumu bu dönemde ekonomik olarak zenginleşmiş ve özellikle büyük şehirlerde, o güne değin etkin olan tutucu ahlak kalıplarından kurtulmuştur. Her ne kadar Birleşik Devletlerin tamamında etkili olduğu söylenemese ve ancak sanayinin geliştiği büyük kentlerde ortaya çıkmış olsa da Flapper kültürü, dönem filmlerinde kendini genel geçer bir kültür olarak gösterir. $O$ güne değin fahişelikle özdeşleştirilen makyajı günlük hayata sokan, erkeklere özgü olarak görülen kısa saçları tercih eden, uzun ve dökümlü giysiler yerine kısa ve dar kıyafetleri tercih eden (Kitch, 2001, 122), içki yasağına rağmen ellerinde şampanya kadehleri, viski bardakları ile partilerde boy gösterirken ağızlıkla içtikleri sigaranın önüne çakmak tutan centilmen erkekleri dizen Flapper kadınları eril bakışın şekillenmesinde ciddi anlamda etkili olmuşlardır. Bu kültürün en önemli ifşası olarak addedilen It (Yön: Clarence G. Badger, 1927) adlı filmde bir Flapper kadını olan Betty Lou'nun, filmin finalinde evlilikle ve erkeğe teslimiyetle sonlanacak yükselme öyküsü anlatılır. 'Kükreyen Yirmiler' şanına uygun bir gösteriş ile son bulan film yaşam tarzından bağımsız olarak kadınları erkeklere eş olarak tasarlar. Kadınların yaşamları boyunca peşinde koştukları mutluluk parmaklarındaki alyansta ve eşi olan erkeğin kollarındadır. Film boyunca izleyici tarafından uçarılıkla suçlanan ana kadın karakter, filmin sonunda, tüm salon tarafından takdir edilmekte ve evlilik kararı ortak bir yetkeyle onaylanmaktadır.

Zamanla bir anlaşma haline gelmiş olan bu kavrayış biçimi, özellikle Hollywood stüdyo sistemi tamamen çökene kadar etkisini korumuştur. Bununla birlikte 1920'lerin sonunda yaşanan ve Büyük Buhran adı verilen ekonomik krizle birlikte ABD içi -ve dışı- tüm endüstriler ciddi olarak mali çöküşler yaşamışlardır. Her ne kadar 1930 yılını tarihinin kâr rekoru ile kapatmış olsa da takip eden yıllar Hollywood için de büyük ekonomik çalkantılara neden olmuş ve Amerikan sinema endüstrisi bir bütün olarak, 
her zaman sattığından emin olduğu iki temaya yönelmiştir: şiddet ve cinsellik. Şiddet gangster filmleri ile hayat bulurken cinsellik düşmüş kadın / metres (fallen woman / kept woman) filmleri ile hayat bulur. Ancak bu filmlerdeki cinsellik, günümüzdeki gibi şeffaf bir cinsellik değildir; örtüktür ve bir düşünce olarak hayat bulur. Erkek olduğu varsayılan izleyiciye sunulan varsayılan bir cinsellik. Ekonomik nedenlerden dolayı kötü yola düşen ama yine de iyi ahlakını yitirmeyen kadınların kocalarının yüce gönüllülükleri sayesinde kurtarıldıkları 'düşmüş kadın / metres' filmleri arasında Red Headed Woman (Yön: Jack Conway, 1932) özel bir yere konmalıdır. Zira Hollywood sinemasının 50 yıl sonra uygulayacağı tematik bir dönüşün ilk örneğini verir. Jean Harlow'un canlandırdığ ‘ 'Red’ Andrews Legendre isimli ana karakter yükselmek için cinselliği kullanmaktan çekinmeyen, bundan da -filmin finalinde dahi- esef duymayan ve bu yöntem ile zenginliğe ulaşan bir kadındır. Ayrıca eril bakışa çıplaklığını (gögüs ucunu ve bacaklarını) göstermekten de çekinmemektedir. Sahip olduğu fiziksel nitelikleri, tıpkı tipik erkek kahraman gibi (kaba kuvvet, cesaret, silah kullanma becerisi) amacına ulaşmak üzere kullanmaktadır.

Red Headed Woman bu çalışmanın temel argümanlarının erken dönemde sorgulamaya açan önemli ama adı pek bilinmeyen bir örnektir. Zira bu film özelde çıplaklığın, genelde ise cinselliğin, kadın lehine, bir güç olarak kullanılabileceğini göstermektedir. Bu silah birbiriyle bağlantılı olan iki katmana yönelir. Ön katman, perdede yansıyan (genelde ana karakter olan) erkek kahramandır. İkincil ve arka katman ise, perdenin ardındaki eril bakışın sahibi izleyici katmanıdır. Özellikle Büyük Buhran sonrası yaşanan hem bireysel hem de toplumsal- iktidar kaybı söz konusu olduğunda çıplak/cinsel kadın karakterin cezalandırılması eril bakışın endişelerini gidermektedir. Çünkü John Berger'in 1972 yılında, Laure Mulvey'den bile önce, belirttiği gibi kadın her zaman erkeğin gözleri ile resmedilmiş ve doğal olarak tüm eserlerde erkeğe kendini beğendirecek ve güçlü hissettirecek şekilde konumlandırılmıştır (Fırıncıoğulları, 2013, 27). Avrupa resim sanatındaki bu saptama sinema için de geçerlidir. Filmlerde, alışıldık biçimde kadının cezalandırılması ile kadın, özelde erkek karakter genelde ise eril bakış karşısında ayartma gücünü yitirir. Daha 1980 sonrasında da görüleceği üzere, Red Headed Woman filminde de bu cezalandırma ve eril endişenin erkeğin iktidarını yeniden tesis etmek üzere giderilmesi sekteye uğramakta ve ayartma/ayartılma tehdidi devamlı kılınmaktadır. Bu sayede de Hollywood ayartma tehdidine karşı eril bakışın tahayyül ettiği toplumsal cinsiyet algısını teyakkuzda tutmayı, daha aktif gale getirebilmeyi başarmıştır (özellikle doksanlı yıllarla birlikte). 
1930'ların ortasında, ekonomik krizle birlikte güç kazanan muhafazakâr kitleler, Hollywood üzerine ciddi bir kendi kendini düzenleme (sansür) yasası dayatmayı başarmışlar ve bunun sonucunda da Büyük Buhran sonrasına ait olan film türleri derhal yok olmuşlardır. II. Dünya Savaşı'na kadar da cinselliği kullanan kadın karakter anaakım Hollywood'da etkili olmamıştır.

ABD'nin II. Dünya Savaşı'na girişi ve Avrupa'ya yoğun biçimde asker sevkiyatı gerçekleştirmesinin ardından ülke genelinde ciddi bir iş gücü sorunu ortaya çımış, iş yaşamında gerçekleşen bu boşluk "neredeyse bir gecede kadınlar, okulu bırakmış gençler (teenagers), Meksikalı göçmenler, zenci marabalar, çok yoksul göçebeler ve hatta, küçük boyutları uçak kokpitlerinde çalışmaya elverişli olduğu için, cücelerle doldurulur." (Lippman, 2009, 176). Büyük Buhran'ın yol açtı̆̆ı ekonomik krizden II. Dünya Savaşı sayesinde kurtulan ABD, bu savaş boyunca tam istihdamı sağlamış, sendikalarıyla tam uzlaşmayı elde etmiş ve tarihinin en refah dolu dönemini yaşamıştır.

Savaş döneminde kadının ekonomik olarak güç kazanması ve erkeklerden- bağımsızlaşmasına Hollywood'un yanıtı hiç gecikmemiştir. Beyaz perdede yuvalarından ve kocalarından bağımsızlıklarını koparmayı arzulayan güçlü, istekli ve baştan çıkarıcı kadınlar görülmeye başlamıştır. $\mathrm{Bu}$ kadın karakterin genel adı femme fatale yani ölümcül kadın olarak belirlenmiştir. Dişil izleyici için de bir arzu nesnesi olabilecek bu kadın aynı zamanda, eril izleyici için de, bir cinsel arzu/nesne'dir. Ancak tehlikesi de burada yatmaktadır zira anlatı içinde erkek karakteri çıplaklığı ve cinselliği ile baştan çıkardıkça bu karakterin mahvına neden olmaktadır. Bu nedenle eril bakışı dizginleyen ve bağımsız kadının tehlikelerini yeniden gözler önüne seren bir figür olma niteliğini korumaktadır. Bu nedenle femme fatale hem erkek hem de kadın izleyici için bir uyarı ve tehdit mekanizmasını dolayımlar; bu kadının büyüsüne kapılanlar (film içindeki erkek karakterler ve perde önündeki izleyiciler) için sslah edici ve ibret verici bir süreci deneyimlerler.

Anneke Smelik (2008) Feminist Sinema adlı eserinde vamp kadınların beyaz perdeyi terk etmesiyle kadın seyircinin bir kayıp yaşadığını belirtir ve şöyle bir tespitte bulunur: "Sinema, seyircide, anneyle bütün olduğu ve biseksüel nitelik taşıdığı ödipal-öncesi evreye dönme arzusu uyandırır. Dolayısıyla, dişil seyirci sinemadaki güçlü femme fatale karakterle özdeşleyip haz alabilir. Bu, dişil ya da eril seyircinin kendini güçlü anne imgesine bağlamak istemesiyle, sembiyotik ilişkinin bir şekilde yeniden canlandırılmasıdır" (Smelik, 10). Ancak diğer yandan ölümcül kadının ağına düşmek ile onunla özdeşleşmek arasında bir fark olmadığı açıktır zira femme 
fatale hem erkek hem kadın için yanlış bir kılavuzdur ve göstermelik bir bağımsızlık altında bu bağımsızlığın cezalandırılması düşüncesini içerir. 1980 ve sonrası Hollywood sinemasında da yeniden görüleceği üzere, bu yeni kadın -karakter- tavrının ve niteliklerinin ideolojik ve sosyo-politik bir paradigma kopuşunu temsil ettiği öne sürülse de, aslında bu paradigmayı, farklı ve yeni bir tarzda, yeniden üretmekten başka bir işlevi yoktur. Bu nedenle Smelik'in olumlu bir nitelik ile savunduğu bu tezin bir kez daha sorgulanması gerekmektedir.

II. Dünya Savaşı ardından yaşanan geri dönüş süreci hem erkeği kaybettiği işe hem de kadını, savaş süresince sadece bir ' $\mathrm{ev}^{\prime}$ ' haline gelen yuvaya geri döndürür. 1950'lerle birlikte yaşanan baby-boom (savaş sonrası yaşanan bebek patlaması) ve banliyölerin gelişmesi kadını iş yaşamından ciddi anlamda koparıp yuvaya ve kocaya bağımlı hale getirirken anaakım Hollywood da bu süreci destekleyecek yapımlara yönelir. 1940'ların ortasında gizliden gizliye sürdürülen kadını baskılama mekanizması popülerleşen melodram filmleri ile artık görünür hale gelir. Öyle ki bu filmler kimi zaman 'kadın filmleri' kimi zaman ise 'ağlak filmler / weepies' olarak adlandırılır. Bağımlı, uyumlu, sabırlı ve ahlaklı kadını yücelten bu filmlerin finalleri, femme fatale'li kara filmlerin aksine, mutlu sonla gerçekleşir. Ancak yapaydır bu mutlu sonlar. Öyle ki Dilek Tunalı bunu şöyle ortaya koyar: "aslında 'mutlu son'; kadın karakterin topluma ya da içinde bulunduğu baskı ortamına (ailesine, çocuklarına, babasına ya da yasaya) karşı çıkışı gibi görünse de, ideolojik ve psikanalitik analizde, bunun kültürel dayatmanın isteği doğrultusunda 'mutlu son'a varan bir final olduğu anlaşılır. Yani duygusal baskıdan kurtuluş farklı türde bir baskı aracıliğılyla elde edilir." (Tunalı, 2006, 44). Ruken Öztürk (2000) ise 1950'lerde reel yaşamda kadınların mutlu yaşamlara sahip olduğunu öne sürerken sinemadaki erkek temsilinde (ve gerçek hayatta da) bir evcimenleşmeden dem vurur ve sert erkeklerin gözden düştügünnü ve genelde ailenin iş yaşamından önde tutulduğunu belirtir (Öztürk, 72). Bu dönüşüm 1960'ların nispeten liberal atmosferine kaynaklık eden faktörlerden biri olacaktır.

1960'lar bağımsız yapımcıların ve yapım şirketlerinin kendilerini iyiden iyiye gösterdikleri bir dönemdir. Stüdyo sisteminin ve buna bağlı olan yapım mantığının tamamen ortadan kalktığı bu süreç Avrupa'dan gelen filmlerin, anaakım sinema filmleri gösteren salonlarda olmasa bile, giderek güçlenen ve sayıca artan Arthouse'larda gösterin fırsatı bulmasına eşlik eder. İzleyici cinsellik konusunda basmakalıp değerleri zorlayan sınırları görmeye başlar. Hollywood sineması da bu eğilime ayak uydurarak eril bakışın -kadın bedeni üzerinde- daha şeffaf bir görüş alanına sahip 
olmasına izin verir. Ayrıca 1968 yılında baskıcı kendi kendini düzenleme sistemi yerini bugün de değişerek kullanılan rating sistemine bırakır. Böylece filmler, içerdikleri şiddet, çıplaklık ve diğer hassas mevzulara göre değerlendirilmekte ve eserler bir bütün olarak yasaklanmamaktadır; birer meta olarak ilgili müşteri kitlesinin ilgisine sunulmaktadırlar. 1930'larda Hollywood'un canhıraş bir telaşla sarıldığı cinsel temalı filmler artık izleyici için geçen 30 yıllık süreçteki kadar ulaşılmaz değildir. Cinselliğin de anlam yaratmadaki gücü kabul edilmiş ve anaakım Hollywood sineması tarafından da kullanılmıştır.

$\mathrm{Bu}$ dönüşüme, toplumsal atmosferi belirleyen yurttaşlık hakları, kadın hakları, yeni sol ve marjinal gençlik hareketleri de eşlik etmektedir. Ekonominin de nispeten bir refah durumunda olduğu ABD toplumunda yukarıda adı geçen toplumsal hareketler içinden yurttaşlık hakları (özellikle Afrika kökenli Amerikan vatandaşlarının kimlik ve temsil bağlamında elde ettiği kazanımlar) ve kadın hakları hareketleri ön plana çıkmış ve sonraki yıllarda varlıklarını korumuşlardır. Feminist hareket ve sinemanın feminist okumaları da bu döneme denk gelmiştir.

Sinema üzerine feminist yaklaşım, psikanalitik film okumaları da arkasına alarak giderek güç kazanmış ve kısa sürede, anaakım içinde olmasa bile, özellikle deneysel sinema bazında önemli örnekler vermiştir. Bunun nedenleri çeşitlidir ama en belirgin olanı anaakım içinde alternatifsizmiş gibi görünen eril bakışı değiştirmenin ve bu eril bakışın yargısını ve hükmünü olumlayan mekanizmaları kırmanın güçlüğüdür. Bu nedenle feminist film yapımcıları konvansiyonel sinema anlayışına karşı çıkacak yöntemleri deneysel sinema tarzı içinde kullanmışlardır.

1970'ler ekonomik krizler ve buna bağlı olarak toplumsal muhafazakârlaşma ile başlar. Ayrıca bir önceki dönemin radikal toplumsal hareketleri de kendi karşıtlarını yaratmışlar ve bu muhafazakârlığın güçlenmesine neden olmuşlardır. Bu toplumsal atmosfere paralel olarak güçlü ve liberal yasaların altında ezilmeyen bireyci erkek kahraman ortaya çıkmakta gecikmemiştir. Bu karakter tipinin en önemli örneği Kirli Harry'dir (Dirty Harry, Yön: Don Siegel, 1971). 1980'lere doğru gelirken bu izleği takip eden filmler de artmıştır: Superman (Yön:Richard Donner, 1978), Star Wars (Yön: George Lucas, 1977), ve Rocky (Yön: John Avildsen, 1976) gibi (Kellner ve Ryan, 1997, 33).

Bununla birlikte, Alice Doesn't Live Here Anymore (Yön: Martin Scorsese, 1974) gibi nispeten feminist tavra yakın olarak değerlendirilebilecek filmler beyaz perdede şans bulsa da, neredeyse her ekonomik kriz sürecinde anaakım Hollywood temsillerinde karşılaşıldığ 1 
üzere, çalışan kadını niteliksizleştiren ve kötüleyen yapımlar ortaya çıkmaya başlar. Bunların en önemli örneği Kramer vs. Kramer (Yön: Robert Benton, 1979) filmidir. Bu filmde evladına bağlı bir babanın, oğluna yeterli ilgiyi göstermeyen anneye karşı çatışması gözler önüne serilir. 1980 öncesi süreci özetlemesi açısından son derece önemli olan Kramer eril bakışın kadın üzerinde ve hatta kadınlığa dair nitelikler konusunda bile baskın olduğunu ortaya koyan ve izleyiciyi bu açıdan şüpheye bırakmayacak biçimde ikna eden bir yapimdir.

1980 sonrası Hollywood sinemasında kadınların temsiline ilişkin niceliksel bir değişimden söz edebilmek mümkündür. Bu değişime yol açan parametreleri 1970'lerde yükselen ve daha sonrasında da devam eden feminist hareket ile bağlantılı bir biçimde değerlendirmek gerekir. Ne var ki söz konusu değişim ne toplumsal yapıda ne de Hollywood sinemasının ana damar kodlarında bir paradigma dönüşüme yol açmamış görünmektedir. 1960'lar ve 1970'ler boyunca ABD'de hem Hollywood'un içinden hem de dışından daha özgürlükçü sinemasal söylemler yükselmeye başlamışsa da, 1980'lerde yükselen yeni-sağ dalgaya paralel olarak, daha muhafazakâr ve ata erkini savunan bir anlayışın da yükselmeye başladığı görülmektedir. 1968 'de neredeyse bilinen tüm dünyayı etkisi altına alan devrimci hareketlerin kısmen yenilgiye uğraması ise mücadelenin seyrini değiştirmiş ve bu mücadele kendisini kimlik siyasetlerinin içinde daha derinden hissettirmeye başlamıştır. Toplumsal cinsiyetlerden, etnik kimliklere, sömürgecilik karşıtı mücadelelerden hayvan hakları savunucularına kadar pek çok alanda vücut bulmuş görünmektedir. 1980 sonrası Hollywood'da yaşanan değişimi, Ronald Reagan, Margaret Thatcher, Helmut Kohl gibi muhafazakâr, militarist, cinsiyetçi ve zaman zaman faşizan eğilimlere sahip siyasal yaklaşımların iktidara gelmesi ile yükselen yeni kimlik siyasetlerinin pratikleri arasinda okumak gerekecektir.

Laura Mulvey (1975) "Görsel Haz ve Anlatı Sineması" metninde, özellikle Klasik Hollywood Sinemasının erkek izleyicinin bakışına göre kendisini kurduğunu, kadını da bu bakışa göre konumlandırdığını dile getirir. Böylelikle karşılaştığımız filmler eril bir sinema modeli ortaya koyarlar. 1970'lerde gelişmeye başlayan feminist hareket ile birlikte düşünüldüğünde Mulvey'in metni ve ortaya koyduğu sonuçlar önemlidir ve bu öneme müteakip olarak uzun yıllardır film kuramının kimi damarlarını beslemektedir. Ne var ki sinema kuramı açısından böylesi kavramsal izleyici modellerinden yola çıkmak sıkıntılı sonuçlara yol açabilir. Hollywood sineması baştan aşağı yekpare bir yapı değildir. Onun içinde üretilen filmler farklı siyasal çatışmaların izlerini taşır ve modellerini buna göre inşa eder. 
Kuşkusuz ki yapım aşamasını belirleyen en önemli unsur gişe üzerinden yakalanacak beklentilerdir, bu sebeple fabrikasyon bir sistem içinde üretilen filmler daha başlangıçta meta statüsüne sahip olarak ortaya çıkarlar. Böylelikle her ürün daha büyük gişe, farklı izleyici kitlelerini çekmek vb. stratejiler çerçevesinde bazen geleneksel olan kalıpları devam ettirirken bazen de "yeni" olan denemeleri uygularlar. Hâlihazırda mevcut, kendisi için film üretilen, sabit bir izleyici kitlesi yoktur. 1980 sonrası Hollywood'da kadın temsillerine ilişkin yeni tarzda filmlerin ortaya çıkmasını da bu bağlamda değerlendirmek ve buradaki "yeni" kavramını metadaki yeni olarak kavramak gerekecektir. Şimdi bu bağlamda bir dizi filme bakabiliriz.

Body Heat (Yön: Lawrence Kasdan - 1981) filmi bu anlamda sembolik bir öneme sahiptir. Kasdan'ın filmi 1940'ların atmosferini ve aynı zamanda da o döneme Hollywood'da damgasını vuran Film Noir stilini yeniden üreten retro bir filmdir. Bu dönemin filmlerine aşina olanların da farkına varmış olacağı gibi, baştan çıkaran, tehlikeli kadın karakter, nam-ı diğer femme fatale 1940'ların filmlerinde her zaman işlediği suçların cezasını çekerken, ki bu ceza çoğu kez onun ölümü olur, Kasdan'ın filmi burada değişime giderek filmin sonunda kadın karakterin kazanarak olaylardan çıkmasını sağlar. Burada üzerinde durulması gereken bazı önemli noktalar vardır. Öncelikle film kendi tarihsel döneminin toplumsal sorunlarını tarihselleştirerek ortaya koymaz. Özellikle Brecht'te sıklıkla gördüğümüz tarihselleştirmeye dayalı bir estetik anlayış, sorunsalını, tarihin dolayımları ile daha derin bir düşünümsellik içinde ortaya koymaya çalışır. Amaç öncelikle izleyicinin kendi şimdisine bilindiği varsayılan bir tarihsel durumun perspektifi sayesinde bakmasıdır. Oysa ki Kasdan'ın yararlandığ 1 retro bir tarih anlayışına dayanan yapılanma şimdiyi anakronik bir biçimde tarihsel bir döneme yansitır. Aslına bu 1970'lerden beri gelişen postmodern bir estetiğin parçasıdır. Bu estetik yaklaşımın ve bundan türeyen yapımların, modernizmin ve modernitenin büyük anlatılarının çöktüğü fikrini paylaşması, kadın temsillerinde yaşanan değişimin niçin nicel boyutta kaldığının anahtarını da vermektedir. Cinselliğin gösterimi paradigmada yaşanan bir kopuş değil, ama değişim sonrasında ima düzeyinden şeffaflık düzeyine geçmiştir.

Femme fatale figürünün 80 sonrası Holywood'daki değişimi noktasında en sansasyonel film ise Basic Instinct (Yön: Paul Verhoeven 1992) olmuştur. Sharon Stone'un canlandırdığı Catherine Tramell karakterinin "aşırı" cüretkârlığı erkek dünyasını ve ona ait olduğu varsayılan bakışı (gaze/nazar) tehdit eden yıkıcı bir Şey'e (The Thing) dönüşür. Bakış kavramı 1960'ların politik atmosferinden hem etkilenmiş 
olan hem de onu etkileyen iki önemli düşünürde, Foucault (1992) ve Lacan'da (2013) nesnenin tarafında yer alan bir olgu olarak değerlendirilir. Özneler kendilerini bu bakışın ekseninde kurarlar. Bu anlamda filmin başına yer alan, Catherine'in polisler tarafından sorgulandığı sahnede, bacak bacak üstüne atarken vajinasını gösterdiği sahnede, bakışın Catherine'nin tarafında olduğunu söylemek gerekecektir. Hem muhafazakâr, ataerkil toplumun hem de sorgu sahnesinde sorgulayan konumunda bulundukları için özne konumunu erkekler işgal eder, kadın ve özelde de Catherine tüm bu sürecin nesnesidir. Yaptığı hareket tam da bu nesne konumuna uygun olarak kendisini seyreden erkeklere bakmak (ama gözleri ile değil tabii ki) ve bu sayede bakış ile karşılaşan erkeklerin "iktidarını" sarsmaktır. Burada bakışın hali hazırda mevcut bir nesne olmadığını, aslına bir tür boşluk ya da yokluk olduğunu ancak öznenin edimi sayesinde vücut bulduğunu da hatırlatmamız gerekir. Ne var ki filmin bu özne-nesne konumlarını bakış ile dolayımlayan yaklaşımını, cinselliği ön plana çıkartılmış bir aşk ilişkisi ve cinayetler konusunda izleyicisini muallakta birakan stratejisi ile mutenalaştırdığını da göz önünde tutmak gerekir. Böylelikle filmin kadının konumunu ele alışındaki "radikalliği" bir söylem biçimine dönüşmez, sadece pazarlanması noktasında bir imaj işlevi görür.

Last Seduction (Yön: John Dahl - 1994) filmi, femme fatale figürünün kötücüllügü noktasında daha ileriye gider. Bridget karakteri doktor olan kocasına yasadışı ilaç sattırtarak kazandıkları bütün parayı alıp onu terk eder. Küçük bir barda tanıştığı genç adamın testislerini avuçlar ve "malımı kontrol etmeden almam" der ve tüm bunların sonunda da kazanır. "Kötü" olan cezasız bırakıldığı gibi, erkeğe ait tüm dünya da avuca alınıp aşağılanır. Ana damar Hollywood sineması içinde bunun en ileri giden filmlerden birisi olduğuna kuşku yoktur. Bir kadın cinselliğini ve güzelliğini kullanarak istediği her şeyi elde edebilir. Zizek de filmin, erkek dünyasına yönelik tüm yıkıcı söyleminin ardında, gene erkek fantezisine ait dünyanın olduğunun altını çizer; “... Yani, yeni film noir'ın femme fatale'ini Hayes Yapım Yasası'nın çözülmesi bağlamına yerleştirmek gerek: 40'ların sonunda ancak ima edilen şey, artık açıkça konu edilir olmuştur. Yeni film noir'da cinsel karşılaşmalar soft pornografiye yaklaşacak kadar açıktır..." (Zizek, 2001, 27-28)

Bu dönem boyunca çekilen filmlerde, erkek dünyasına karşı çıkan, onu tehdit eden, ataerkil yapıyla arasına eleştirel bir mesafe koyan filmler sadece kadının femme fatale olarak temsil edilmesi üzerinden gelmemiştir. Silence of The Lambs (Yön: Jonathan Demme - 1991) filmi ve gene ayn yıl vizyona giren Thelma \& Louise (Yön: Ridley Scott - 1991) filmi kuşkusuz dönem açısından önemliydiler. Bu filmlerin geçmişle bağlantıları vardır. 
Alien (Yön: Ridley Scott - 1979) filmi ve çok daha erken tarihli olan The Childeren's Hour (Yön: William Wyler - 1961) kadının böylesi temsillerini önceden haber verirler. 80'li 90'lı yıllar boyunca kadınların toplumsal hayata çok daha yoğun bir biçimde katıldıkları düşünülecek olursa, bu filmler aslında gecikmiş yapımlardır. Silence of The Lambs filminde erkek dünyası içinde güçlü kadın figürüne paralel olarak temsil edilen travesti, psikopat katil figürü düşünülecek olursa, filmin toplumsal cinsiyetlerin sosyo-siyasal konumları noktasındaki söyleminin problemli olduğu söylenebilir. Diğer yandan The Childeren's Hour ve ThelmaELouise toplumsal cinsiyet noktasında, iki kadın arasındaki sosyal ilişkiler ve lezbiyenlik temaları ile dolayımlanmaktadır. İki kadın arasındaki ilişki toplumsal dokuda açılmış bir yara gibi görünmektedir. Bir yandan bu ve benzeri filmlerin yarattı̆̆ 1 atmosfer diğer yandan da noir geleneğinden beslenen Bound (Yön: Andy \& Lana Wachowski - 1996) filmi, sinemada lezbiyenlerin temsillerinin popülerleşmiş versiyonlarından birisini sunar. Filmde lezbiyen ilişkinin olumlanarak ele alınması, cinsel politikalar bağlamında düşünüldüğünde, erkek fantezi dünyasının bir parçası olmanın ötesine geçmemektedir. Gene Wachowski kardeşlerin çekmiş oldukları Matrix (Yön: Andy \& Lana Wachowski - 1999) filmindeki Trinity karakteri ve bilgisayar oyunlarından kaynaklanan "yeni" bir ölümcül kadın figürü doğacaktır ama bundan önce klasik femme fatale figürünü devam ettiren bir film olarak Femme Fatale (Yön: Brian de Palma - 2002) dikkat çekicidir. Film lezbiyen ilişki, bir kadının güzelliğini ve seksiliğini kullanarak hemen tüm erkekleri baştan çıkartması gibi bildik temalar üzerine kuruludur. Filmi ilgi çekici kılan deja vu mantığıyla çekilmiş olması ve kadının kendi içinde bir arınma geçirmesi üzerine kurulmuş olmasıdır. Buradaki arınma, tarzın 1940'lardaki klasik döneminde gerçekleştirilen günah çıkarma sahneleri hatırlatır. Böylelikle toplumsal ahlak ve onun statükoları bir kez daha onaylanmış olur.

Diğer yandan Hollywood sinemasinda tüm bu yıllar boyunca paradigmada bir kopuş yaşanmamışsa da kimi yönetmenler kendi bireyse sinemalarında bu kopuşun hala bir imkân olarak sürdügünün belirtilerini de ortaya koydular. Bu yönetmenlerden en sansasyonellerinden birisi David Lynch oldu ve onun Lost Highway (Yön: David Lynch - 1997) filmi, sinemada ölümcül kadın figürünün oldukça ayrıksı bir temsilini gerçekleştirdi. Lynch'in filmi toplumsal sistem içinde erkeğin iktidarsızlığını göstermeyi son noktaya kadar taşıyarak, hem gerçeklik evreninde hem de fantezi evreninde bu durumun altını çizdi. Kadının öldürülmesi (ya da cezalandırılması) toplumsal düzeni, ata erkini yeniden tesis etmek için gerekli bir eylem olmaktan çıarken, Lynch bunu tam tersine çevirerek bu 
eylem sayesinde toplumsal gerçekliğin ve onun ahlakının yıkılışını seçti. Bu anlamda Lost Highway filmi Hollywood sinemasinin neden yeterince radikalleşemediğini, en fantastik örneklerinde dahi toplumsal gerçekliğin kurallarına nasıl boyun eğdiğini bir kez daha göstermiş oldu.

2000'li yıllarda popülerleşen Underworld, Lara Croft, Resident Evil gibi filmler ise ölümcül, tehlikeli kadın figürünün yeni bir versiyonunu sundular. Bu filmlerdeki kadın karakterler artık toplumsal değerlerle çatışan bir konumda değillerdi, aksine ait oldukları fantastik dünyalarda mevcut değerleri onaylayan ve bunun için savaşan, mücadele eden bir perspektifi benimsediler. Vücutlarının tamamını saran catsuit kıyafetler ya da benzeri seksapel kostümlere tezat bir biçimde çoğu kez cinsellikten arındırılmış bir biçimde temsil edildiler. Kendilerine kaynaklı eden bilgisayar oyunlarında olduğu gibi büyük oranda15-30 yaş arası erkeklerden oluşan bir kitleyi hedeflediler. Söz konusu karakterler cinselliğe ait göstergelerinin aşırılaşmasına paralel bir biçimde cinsiyetsizleştirildiler.

Sonuç olarak hemen tüm tarihi boyunca Hollywood sinemasında kadın bedeni ve onun gösterim biçimleri hem bir mücadele alanı hem de filmleri pazarlama stratejisinin bir parçası olmuştur. Toplumsal yaşamda yaşanmaya başlayan değişimlere paralel olarak kadın bedeninin temsil biçimleri de değişmiştir. Bu değişim Hollywood'un sıklıkla başvurduğu femme fatale tiplemeleri ya da karakterleri için de geçerlidir. Günümüze yaklaştıkça, cinselliğin ve bedenin daha açık gösterimlerinin nedenlerini, Hollywood sinemasının demokratikleşmesinden çok tüketim toplumunda ve buna bağlı olarak imajların şeffaflaşmasında aramak gerekecektir.

\section{Kaynakça}

FIRINCIOĞULLARI, S. (2013). John Berger / Görme Biçimleri. Özne, 5, 27-31. FOUCAULT, M. (2003). İktidarın Gözü. Çev: Ergüden, I. İstanbul : Ayrıntı.

KITCH, C. (2001). The Girl on the Magazine Cover. Chapel Hill: University of North Carolina Press.

LACAN, J. (2013). Psikanalizin Dört Temel Kavramı. Çev: Erdem, N. İstanbul: Metis.

LIPPMAN, D. H. (2009). Labor and Employment. Carlisle, R. P. (der), The Great Depression and the World War II içinde, New York: Facts on File.

MULVEY, L. (1975). Visual Pleassure and Narrative Cinema. Screen 16:3 Autumm. London: Oxford Journals.

ÖZTÜRK, S. R. (2000). Sinemada Kadın Olmak. İstanbul: Alan Yayıncilık.

RYAN, M. Ve Kellner, D. (1997). Politik Kamera. İstanbul: Ayrıntı. 
SMELIK, A. (2008). Feminist Sinema ve Film Teorisi. Çev: Koç, D. İstanbul: Agora Kitaplığl.

TUNALI, D. (2006). Batıdan Doğuya, Hollywood'dan Yeşilçam'a Melodram. Ankara: Aşina Kitaplar.

ZIZEK, S. (2001). Gülünç Yücenin Sanatı. Çev: Kılıç, S. İstanbul: Om Yayınları. 
B. BAKIR, E. S. ONAT | 102 